tain a neutral $p \mathrm{H}$, in which condition the selective absorption of sugars is greatest.

F. Ponz

J. LARRALDE

Laboratory of Animal Physiology,

University of Barcelona. June 21.

${ }^{1}$ Magee, H. E., and Reid, E., J. Physiol., 73, 181 (1931).

2 Wilbrandt, W., and Laszt, L., Biochem. Z., 259, 398 (1933).

${ }^{3}$ Laszt, L., Biochem. Z., 276, 40 (1935).

- Cajori, F. A., and Karr, W. G., J. Biol. Chem., 109, xiv (1935).

${ }^{5}$ Westenbrink, W., Acta brev. N6erl. Physiol., 6, 36 (1936).

- Gellhorn, E., and Moldavsky, L. E., Amer. J. Physiol., 109, 638 (1934).

? Sols, A., and Ponz, F., R, Esp. Fisiol., 3, 207 (1947).

B Vidal-Sivilla, S., Sols, A., and Ponz, F., R. Esp. Fisiol., 6, 195 (1950).

\section{Gene Function in the Homologous and Heterologous Induction of $\alpha$-Glucosidases in Yeast by $\alpha$-Glucosides}

A VARIETY of freely segregating genes which specifically control the abilities of yeast to ferment $\alpha$-glucosides has been discovered ${ }^{1,2}$. The three nonallelic genes determining the abilities of the haploid yeasts of the Carbondale breeding stock to grow with attendant visible gas evolution on maltose, $\alpha$-methyl glucoside and sucrose, respectively, have been designated $M A / m a, M G / m g$ and $S U / s u$. It has been shown that these genes are concerned in the synthesis by the cell of maltase, an $\alpha$-heteroglucosidase $^{3}$ and $\beta$-fructofuranosidase, respectively.

Experiments in which the variation of the fermentative scope of cells of genotype $M G M A s u$, $m g M A s u$, and $M A m g$ su was determined in relation to the carbohydrate component of the growth medium of these cells have now permitted a fuller definition of the functions of $M A$ and $M G$. Although the strains of these genotypes lack the gene $S U$, that is, they are incapable of growing with attendant visible gas evolution on medium containing sucrose as the sole carbohydrate nutrient, they all proved capable of sucrase synthesis when grown on a suitable carbohydrate. The sucrase activity which could be induced in these strains was frequently held largely in a covert condition by the freshly harvested cells, but was manifested by the same cells after drying. The strains realized only a small or negligible fraction of their glucosidase synthesizing potential when they were grown on glucose. In the strains containing the gene $M A$ without $M G$, growth on maltose elicited a homologous response (maltase synthesis) and a heterologous response (synthesis of a sucrase). The growth of these strains on maltose failed to endow them with ability to ferment methyl glucoside at a significant rate. The strains of this genotype were incapable of responding to $\alpha$-methyl glucoside with production of either maltase, $\alpha$-methyl glucosidase or sucrase. In the strains containing the gene $M G$ without $M A$, growth on $\alpha$-methyl glucoside elicited a homologous response (production of $\alpha$-methyl glucosidase), and a hetero-response (production of a sucrase). The growth on $\alpha$-methyl glucoside failed to endow these strains with ability to ferment maltose. The strains of this genotype were incapable of responding to maltose with production of maltase, $\alpha$-methyl glucosidase, or sucrase. Strains containing both $M A$ and $M G$ responded to both maltose and $\alpha$-methyl glucoside with sucrase synthesis. In these strains maltose also elicited $\alpha$-methyl glucosidase as well as maltase activity. When the cells of these strains were grown on $\alpha$-methyl glucoside, they fermented the latter but not maltose on contact. They proved able, however, to adapt themselves to maltose more rapidly after growth on $\alpha$-methyl glucoside than after growth on glucose.

The observed effects of the single gene changes in genotype $M G M A s u$ on the response pattern of the strains to $\alpha$-glucosides are summarized in the accompanying table.

\begin{tabular}{|c|c|c|c|c|c|}
\hline \multirow{2}{*}{$\begin{array}{c}\text { Gene altera- } \\
\text { tion }\end{array}$} & \multicolumn{5}{|c|}{$\begin{array}{l}\text { Responses elicited by a-glucosides : } \\
\text { Maltose a-Methyl glucoside }\end{array}$} \\
\hline & Maltase & Sucrase & $\begin{array}{c}\text { a-Methyl } \\
\text { glucosidase }\end{array}$ & Sucrase & $\begin{array}{c}a \text {-Methyl } \\
\text { glucosidase }\end{array}$ \\
\hline \multirow{2}{*}{$\begin{array}{c}M G \text { replaced } \\
\text { by } m g \\
M A \text { replaced } \\
\text { by } m a\end{array}$} & + & + & - & - & - \\
\hline & - & - & - & + & $+\cdot$ \\
\hline
\end{tabular}

+ , signifies that the production of the enzyme in response to the inducer was not markedly altered by the noted genic change.

-, signifles that the genic change noted was associated with a large or complete loss of the ability to produce enzyme in response to the

Thus it may be inferred that $M A$ controls the ability of the cells to respond heterologously as well as homologously to maltose, while $M G$ controls their ability to respond heterologously as well as homologously to $\alpha$-methyl glucoside. It has been attractive to consider that yeast $\alpha$-glucosido-hydrolases (maltase, $\alpha$-methyl glucosidase, and gluco-sucrase) derive from a common precursor ${ }^{3}$. On the view that there exists a one-to-one relation ${ }^{4}$ between a gene and an enzyme, we might assume that gene $M A$ with maltose directs the conversion of the precursor into maltase, and that gene $M G$ with $\propto$-methyl glucoside directs the conversion of the precursor into $\alpha$-methyl glucosidase. An economical account of the control of heterologous inductions by genes $M A$ and $M G$ would be afforded by the assumption that primary enzyme products of these genes (maltase and $\alpha$-methyl glucosidase respectively) may be further converted by the cell into other glucosidases.

SHLOMO HESTRIN

Department of Microbiological Chemistry, Hebrew University-Hadassah Medical School, Jerusalem.

Carl C. Lindegren

Biological Research Laboratory, Southern Illinois University, Carbondale, Illinois. July 20.

${ }^{1}$ Lindegren, C. C., "The Yeast Cell" (Educational Publishers, Saint Louis, 1949).

${ }^{2}$ Winge, $ठ$., and Roberts, C., C.R. Lab. Carlsberg, Sér. Physiol., 25, 35 (1950).

${ }^{3}$ Hestrin, S., and Lindegren, C. C., Arch. Biochem., 29, 315 (1950). 4 Beadle, G. W., Chem. Rev., 87, 15 (1945).

\section{Reversible Oxidation of Glucose by Glucose Dehydrogenase}

Ox liver has been shown to contain an enzyme, glucose dehydrogenase, which catalyses the reaction ${ }^{1,2}$ : Glucose + diphosphopyridine nucleotide $\rightleftharpoons$ gluconate + reduced diphosphopyridine nucleotide.

This enzyme has now been purified approximately 125-fold, starting from an aqueous extract of ox-liver acetone powder. The purification procedure consists 